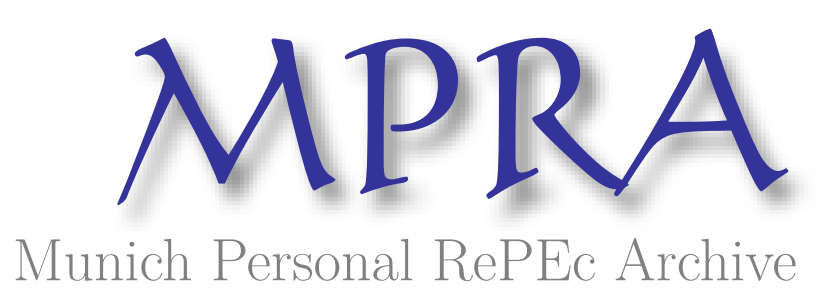

\title{
Does Monetary Policy Matter in China? A Narrative Approach
}

Sun, Rongrong

University of Wuppertal

2012

Online at https://mpra.ub.uni-muenchen.de/45023/

MPRA Paper No. 45023, posted 15 Mar 2013 06:21 UTC 


\title{
Does Monetary Policy Matter in China? A Narrative Approach
}

\author{
Rongrong Sun $^{1}$
}

\begin{abstract}
This paper applies the narrative approach to monetary policy in China to tackle two problems of policy measurement. The first problem arises because the PBC (the central bank of China) applies multiple instruments and none of them per se can adequately reflect changes in its monetary policy. The second one is the classical identification problem: the causation direction of the observed interaction between central bank actions and real activity needs to be identified. The PBC's documents are used to infer the intentions behind policy movements. Three shocks are identified for the period 2000-2011 that are exogenous to real output. Estimates using these shocks and various robustness tests indicate that monetary policy has large and persistent impact on output in China.
\end{abstract}

Key words: exogenous shocks, the narrative approach, real effects of monetary policy

JEL-Classification: E52, E58

\footnotetext{
${ }^{1}$ Schumpeter School of Business and Economics, University of Wuppertal (Gaussstr. 20, 42119 Wuppertal, Germany),

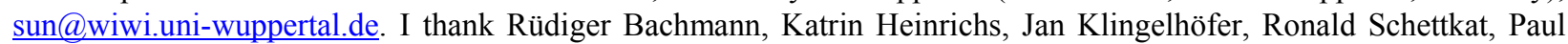
Welfens and seminar participants at the University of Wuppertal and the RWTH Aachen University for their helpful comments. Any remaining errors are my own.
} 


\section{Introduction}

Does monetary policy matter in China? Very few studies have addressed this issue, but reported somewhat mixed findings (see, e.g., Dickinson and Liu 2007; Sun, Ford, and Dickinson 2010). On the other hand, it is a well-established fact that in advanced economies, monetary policy has a significant impact on output (at least in the short run), thanks to numerous contributions (see, e.g., Bernanke and Blinder 1992; Bernanke and Gertler 1995; Blanchard 1990; Friedman 1995; Romer and Romer 1989). Yet, given the substantial differences between China and those economies in their central banking strategies and practices, it is unclear that we can simply extend this conclusion to the case of China. Therefore, it is necessary to conduct an independent study to examine the effectiveness of monetary policy in China.

In order to estimate the effect of monetary policy, first we should be able to measure monetary policy changes (i.e., to describe monetary policy in a quantitative way). The validity of this measure is the premise of an accurate estimate of the effects of monetary policy (see, e.g., Bernanke and Mihov 1998; Romer and Romer 1989, 2004). However, the study of China's monetary policy faces two measurement problems. The first is which policy instrument should be used as a policy indicator. The central bank of China, the People's Bank of China $\left(\mathrm{PBC}^{2}\right)$, does not follow the standard one-instrument operating procedure that advanced economies adopt. ${ }^{3}$ Rather, it uses multiple instruments, including unconventional administrative measures, to achieve various tasks. This operating procedure suggests that all of its frequently-applied policy instruments contain information about its policy (see, e.g., Chen, Chen, and Gerlach 2011; He and Pauwels 2008; Shu and Ng 2010; Xiong 2011). On the other hand, these instruments are different in nature and their changes are not necessarily identical in terms of the frequency and magnitude. None of them per se can represent the behavior of all others and hereby adequately reflect changes in the PBC's policy stance.

The second problem is known as the identification problem in the literature. That is, the causation direction of the observed interaction between monetary policy and economic fluctuations needs to be identified. A simple regression of output on changes in monetary policy is very likely to result in

\footnotetext{
${ }^{2}$ In the literature, two short forms of the People's Bank of China are used: $\mathrm{PBoC}$ and PBC, although the People's Bank of China tags itself with PBC only. In this paper, I follow the Bank's routine and use PBC.

${ }^{3}$ That is, use open market operations with short-term money market rates as the operational target.
} 
biased estimates of the effect of monetary policy as the causation runs in the other direction as well. For example, if the central bank takes counter-cyclical actions and stabilizes the level of economic activity absolutely, "then an observer ... would see (changes in the interest rate) accompanied by a steady level of aggregate activity. He would presumably conclude that monetary policy has no effects at all, which would be precisely the opposite of the truth" (Kareken and Solow 1963: 16). By contrast, economic fluctuations in consequence of exogenous policy movements should reflect the impact of monetary policy, but not other influences (see Romer and Romer 2004). Hence, it is necessary to isolate exogenous components of policy changes from endogenous policy responses.

One approach to overcome these two challenges is the narrative approach, which was pioneered by Friedman and Schwartz in their Monetary History of the United States (Friedman and Schwartz 1963) and has been applied by Romer and Romer in a series of studies (Romer and Romer 1989, 2004). ${ }^{4}$ This approach relies on the reading of the central bank's documents to infer additional information on policy-makers' intentions. The policy stance is identified and in addition, the driving force of each policy movement is detected. Only those policy shifts are defined as exogenous that are not driven by current and future developments on the real side of economy. These shocks are exogenous with respect to the state of the real economy.

One study by Shu and $\mathrm{Ng}$ (2010) has applied the narrative approach to examine monetary policy of the PBC. ${ }^{5}$ They study China Monetary Policy Report, a quarterly executive report of monetary policy of China, and construct a time series of the PBC's policy stance index (tight, neutral or ease, for example). The Shu-Ng index is useful as it can be used as a monetary policy indicator to solve the first measurement problem. However, Shu and $\mathrm{Ng}$ (2010) shies away from the identification problem and their index does not separate exogenous policy changes from endogenous policy reactions. My paper complements Shu and $\mathrm{Ng}$ 's study with another independent reading of the PBC's historical records and singles out exogenous components in policy changes.

This paper uses two sources of the PBC's documents: short summaries of quarterly Monetary Policy Committee's meeting and China Monetary Policy Report. Both documents include explicit statements of the PBC's monetary policy stance for the next period and reasoning of changes in

\footnotetext{
${ }^{4}$ The narrative approach has also been applied in studies on the effect of fiscal policy (see, e.g., Alesina, Favero, and Giavazzi 2012; Ramey 2011; Ramey and Shapiro 1998; Romer and Romer 2010).

${ }^{5}$ Xiong (2011) applies the narrative approach by reading China Monetary Policy Report as well to abstract the information on the PBC's views of macroeconomic conditions.
} 
policy. Based on this information, three exogenous shocks are identified as episodes, in which the PBC shifted policy to contraction to rein in inflation. Estimates using these shocks and various robustness tests indicate that monetary policy has large and persistent effects on output in China. A comparison with other conventional measures suggests that my narrative-based shocks perform better in estimating the effects of monetary policy.

This paper proceeds as follows. Section 2 provides institutional backgrounds of Chinese monetary policy and highlights the monetary policy indicator problem. Section 3 presents a simple framework, explaining why a policy measure with endogenous components is likely to lead to biased estimates. Section 4 identifies three exogenous policy shifts of the PBC through reading its documents. Section 5 examines the impacts of these shocks on output and inflation. Section 6 concludes.

\section{What Measures China's Monetary Policy}

Since the mid-1980s, the PBC has experienced a series of changes in its institutional framework and its operating procedure. Currently, it targets the broad money (M2) and uses multiple monetary instruments to achieve various tasks. Is it possible to measure the PBC's monetary policy with the money stock or one of its policy instruments? In this section, I address the monetary policy indicator problem.

\subsection{Institutional Background}

The PBC was established on December $1^{\text {st }}, 1948$ and was the only bank in China before the economic reforms. It combined the functions of a central bank and commercial banks. ${ }^{6}$ In the 1984 central bank reform, the regular commercial banking activities were separated from the PBC and passed to four newly established (or reorganized) state-owned commercial banks. The PBC was designated exclusively as a central bank. The objectives of its monetary policy are defined in the People's Bank of China Act (promulgated in 1995) as "to maintain the stability of the value of the currency and thereby promote economic growth". The first mandate of the PBC is thus price stability. Meanwhile, the PBC has attached great importance to economic growth. The GDP growth

\footnotetext{
${ }^{6}$ Such a banking system was typical for planned economies, where the central bank functioned mainly as a fiscal agent of the central government in fulfilling the state production plan. The function of financial intermediation remained limited - the investment was financed through budget and on the other hand, private savings were low.
} 
target is set each year by the central government of China to guarantee high-level job creation so as to absorb the consistent labor surplus, either freed from the agricultural sector or as a result of workers being laid-off from state-owned enterprises. One of the major tasks of the PBC is to implement monetary policy in line with this growth target. Along with this mandate, the PBC is actively engaged in foreign exchange interventions to keep the renminbi (RMB) exchange rate within its floating range (it will be elaborated in the next subsection). Thus, the PBC appears to pursue monetary policy with multiple objectives - price stability, economic growth and exchange rate stability.

Until 1997, the PBC implemented monetary policy through the credit plan. The PBC set the quantitative bank-specific loan quotas, which were precise lending ceilings for individual financial institutions, and provided liquidity to those banks, which then allocated credit to governmentpreferred subsectors and projects (see Montes-Negret 1995). Banks adjusted their lending activities to meet the loan quotas. In this way, the PBC, together with banks, worked as fiscal agents to implement the credit plan and thus achieve economic goals. ${ }^{7}$

However, this direct control over the lending quantity of individual banks led to a mismatch between credit supply and demand, hindering the efficient allocation of credits. Furthermore, with the new development of financing sources other than bank credits, the relationship between the credit plan and real GDP became less predictable (see Montes-Negret 1995). In 1996, the PBC introduced the growth rates of monetary aggregates (M1 and M2) ${ }^{8}$ as nominal anchors and adopted them, together with the credit quotas, as its intermediate targets. Two years later, in January 1998, bank-specific credit quotas were formally abolished. ${ }^{9}$ Instead, the PBC started to set the target for the total bank lending and use it as one of its intermediate targets as well. In May 1998, the PBC resumed the open market operations. There is thus a consensus in the literature that the year 1998 is a turning point of the PBC's monetary policy regime from direct to more indirect control (see, e.g., Cao 2001; OECD 2010; Xie 2004), although to some degree, direct monetary control methods still exist. This paper focuses on the post-1998 monetary policy regime.

\footnotetext{
${ }^{7}$ Dickinson and Liu (2007) present an in-depth discussion on how monetary policy affects the real economy in China during this transition period.

${ }^{8}$ According to the PBC, monetary aggregates are M0 (currency in circulation), M1 (sum of M0 plus demand deposits) and M2 (the sum of M1 plus savings and time deposits) (see PBC's Annual Report 2007).

${ }^{9}$ It does not imply, though, that the credit policy has disappeared from the PBC's practices. Today, the PBC still routinely employs specific credit policy tools to control the quantity of credit and affect the structure of credit.
} 


\subsection{Measuring Monetary Policy with M2?}

Some studies use the broad money to measure the PBC's monetary policy, based on the argument that the PBC is targeting M2. Table 1 presents the targeted and actually realized growth rates of monetary aggregates M1 and M2 for the period 1998-2011. ${ }^{10}$ During this period, the broad money, M2, grew consistently at a double-digit rate while the growth rate of M1 showed a higher volatility. In 2009, the growth rates of both M1 and M2 reached a historically high level: 33 percent and 28 percent, respectively, when the PBC injected a huge amount of liquidity into the banking system as a part of stimulus programs.

Table 1: Targeted and actual growth rates of monetary aggregates, 1998-2011

\begin{tabular}{|c|c|c|c|c|}
\hline \multirow[b]{2}{*}{ Year } & \multicolumn{2}{|c|}{ M1 Growth (\%) } & \multicolumn{2}{|c|}{ M2 Growth (\%) } \\
\hline & Target & Actual & Target & Actual \\
\hline 1998 & 17 & 11.9 & $16-18$ & 14.8 \\
\hline 1999 & 14 & 17.7 & $14-15$ & 14.7 \\
\hline 2000 & $15-17$ & 15.9 & $14-15$ & 12.3 \\
\hline 2001 & $15-16$ & 12.7 & $13-14$ & 17.6 \\
\hline 2002 & 13 & 18.4 & 13 & 16.9 \\
\hline 2003 & 16 & 18.7 & 16 & 19.6 \\
\hline 2004 & 17 & 14.1 & 17 & 14.9 \\
\hline 2005 & 15 & 11.8 & 15 & 17.6 \\
\hline 2006 & 14 & 17.5 & 16 & 15.7 \\
\hline 2007 & No Target & 21 & 16 & 16.7 \\
\hline 2008 & No Target & 9 & 16 & 17.8 \\
\hline 2009 & No Target & 33.2 & 17 & 28.4 \\
\hline 2010 & No Target & 20.4 & 17 & 18.9 \\
\hline 2011 & No Target & 8.7 & 16 & 17.3 \\
\hline \multicolumn{5}{|c|}{ Descriptive Statistics } \\
\hline Mean & 15.1 & 16.5 & 16.7 & 17.4 \\
\hline Standard deviation & 1.4 & 6.2 & 1.3 & 3.7 \\
\hline
\end{tabular}

Note: The actual growth rates are computed as percentage changes of the stocks of monetary aggregates at the year end.

Source: The targeted money growth rates over the post-2000 period are the author's compilation (based on various issues of China Monetary Policy Report), while those over the period of 1998-2000 are adopted from Geiger (2006). The actual money growth rates are the author's calculations based on the data from Datastream.

\footnotetext{
${ }^{10}$ The PBC stopped announcing a target for M1 in 2007 but continued to set targets for M2.
} 
A simple comparison of the target and the realized growth rate of M2 indicates that quite often the PBC missed the targets - in most cases, the actual growth exceeded the targets. Can we simply conclude that the $\mathrm{PBC}$ has in those cases implemented expansionary monetary policy? The answer is no. For example, in 2008 and 2011, the PBC explicitly announced contractionary monetary policy and undertook a series of tightening measures (by raising interest rates and the required reserve ratio, for example) to rein in inflation. Yet, M2 grew at a higher-than-target growth rate in both years.

Changes in the money stock thus appear to reflect not only changes in the stance of monetary policy, but other factors. Particularly in China, rises in the money stock could be due to the PBC's foreign exchange purchases. The current managed floating exchange rate regime in China allows a daily movement up to $+/-1$ percent in bilateral exchange rates. ${ }^{11}$ Under this regime, the $\mathrm{PBC}$ is thus committed to stepping in the foreign exchange market to buy or sell foreign currencies whenever the exchange rate hits the bound. Given the current account surplus and the expectation of the RMB appreciation, quite often the exchange rate hit the upper bound and the $\mathrm{PBC}$ had to buy foreign currencies. These operations result in increases in the money supply. To drain the resultant excess liquidity, the $\mathrm{PBC}$ used to take offsetting operations to sterilize the monetary base, though often only partially. The observed changes in the money stock are thus strongly influenced by the strength and magnitude of these interventions. An increase in the money stock cannot be interpreted as monetary easing.

Money demand is another factor that induces changes in the supply of money. A rich literature finds that money demand is far from stable because of technological, institutional, and regulatory changes in the retail banking sector (see, e.g., Friedman and Kuttner 1992, 1996; Goldfeld and Sichel 1990). Central banks in turn accommodate changes in the demand for money. This endogeneity makes it impossible to use the money stock as a proper policy indicator.

\footnotetext{
${ }^{11}$ In July 2005, China announced to give up its decade-long dollar peg and switch to a managed floating exchange rate regime. The exchange rate is thus set "with reference to a basket of currencies", allowing a daily movement up to $+/-$ 0.3 percent in bilateral exchange rates. In May 2007, this daily band was extended to +/- 0.5 percent, and on April 16, 2012 it was further extended to $+/-1$ percent.
} 


\subsection{Measuring Monetary Policy with One Policy Instrument?}

Another practice in the literature is to measure monetary policy with a policy instrument. ${ }^{12}$ In normal times, central banks in advanced economies (for example, the Fed and the ECB) use primarily open market operations on a regular basis to fine-tune movements in short-term interest rates. Other tools play only a minor role in monetary policy. ${ }^{13}$ Thus, there is a consensus to measure monetary policy of the Fed and the ECB with a short-term interest rate. Some studies indeed follow this practice and measure the PBC's monetary policy with a short-term interest rate. However, there is no way to describe the PBC's operating regime as a one-instrument procedure. Rather, the PBC uses various policy instruments to achieve its multiple objectives. Among them, quantity and administrative policy measures play an important role.

Table 2 summarizes policy instruments that the PBC applies, including both monetary and specific credit policy instruments. Monetary policy instruments are presented in the upper panel of the table. They are a mix of quantity and price measures, mainly including open market operations, changes in the required reserve ratios and interest rates.

Many of these monetary policy tools do appear in the list of policy instruments in advanced countries. However, in normal times their central banks in practice mainly use open market operations per se. They seldom change the required reserve ratio and the central bank lending is small in quantity.

By contrast, all these tools play different important roles in China. Quantity measures, open market operations and changes in the required reserve, are used extensively by the $\mathrm{PBC}$ to absorb the excess liquidity in the banking sector through issuing central bank bills and/or raising the required reserve ratio, rather than to meet the operational target of a money market rate (as the Fed and the $\mathrm{ECB}$ do). The PBC relies less on the money market interest rate to affect economic activities. Instead, it exerts direct influences on private saving and bank lending by setting the benchmark deposit rates and lending rates (of various maturities), while commercial banks are allowed to adjust

\footnotetext{
${ }^{12}$ For example, Kareken and Solow (1963: 76) suggested that "( $\mathrm{t}$ )o denote the policy of a particular moment, it is enough to give the values for that moment of the monetary authority's instrument variables".

${ }^{13}$ The 2007 financial crisis has reverted the attention of those central banks to "unconventional" monetary policy instruments, among which quantitative easing has been the most widely used.
} 
interest rates around the benchmark within a limited band. ${ }^{14}$ Recently, the PBC uses the price tool less intensively. Instead, it influences economic activities essentially through quantity tools, by controlling the quantity of money and hence the supply of bank loans.

\section{Table 2: Policy instruments applied by the PBC}

\begin{tabular}{|c|c|}
\hline \multicolumn{2}{|c|}{ Monetary policy instruments } \\
\hline Open market operations & $\begin{array}{l}\text { Quantity-based indirect tool, including repurchases transactions, } \\
\text { outright transactions } \mathrm{s}^{\mathrm{a}} \text { and the issuance of central bank bills } \text {. }^{\mathrm{b}} \text {. }\end{array}$ \\
\hline Required reserve ratio & Discretionary and more direct tool. \\
\hline Interest rates & $\begin{array}{l}\text { Price-based tool, including various central bank base interest rates } \\
\text { The deposit rate and lending rate of commercial banks are highly } \\
\text { regulated. }\end{array}$ \\
\hline \multicolumn{2}{|c|}{ Specific credit policy instruments } \\
\hline $\begin{array}{l}\text { Specific central bank } \\
\text { lending schemes }\end{array}$ & $\begin{array}{l}\text { Discretionary tool. Under certain specific eligibility requirements, } \\
\text { the PBC provides special funds at a lower cost for a particular } \\
\text { group of industries or regions. }\end{array}$ \\
\hline Window guidance ${ }^{\mathrm{d}}$ & $\begin{array}{l}\text { Administrative tool in a form of "moral suasion" or "indirect } \\
\text { pressure" through regular meetings with commercial banks so as to } \\
\text { influence the quantity and the structure of bank lending. }\end{array}$ \\
\hline
\end{tabular}

\footnotetext{
Notes: a. Outright transactions include outright purchase and outright sale, by which the PBC buys/sells securities directly from/to the secondary market to increase/decrease base money. b. Central bank bills are short-term securities issued by the PBC, which were introduced in 2002 to deal with the inadequate supply problem of government bonds. Through issuing central bank bills, the PBC can effectively reduce the money supply. The PBC has used them extensively to offset rises in liquidity in the banking system as a result of the PBC's foreign exchange purchases. Therefore, central bank bills are often referred as sterilization bonds. c. They include the central bank lending rate, the rediscount rate, the interest rates paid on the required and excess reserves. d. The Bank of Japan exercised this practice as well in the post-War era until the early 1990s.

Source: Author's summary.
}

Monetary policy instruments are supplemented by specific credit policy tools, as listed in the lower panel of Table 2. The PBC believes that the development and implementation of credit policy is one of its important duties, as stated on its webpage (see People's Bank of China 2012). Quite often, the PBC launches specific central bank lending schemes, under which it provides special funds at a lower cost for a particular group of industries or regions, and holds regular meetings with commercial banks in a form of "indirect pressure" so as to window-guide "financial institutions to strengthen the extension of supporting loans for central government-invested projects" (China

\footnotetext{
${ }^{14}$ At the moment, the band for the lending rate is $[0.9, \infty)$ and that for the deposit rate is $(-\infty, 1]$. Only in 2004 , the PBC abolished the lending-rate ceiling and the deposit-rate floor.
} 
Monetary Policy Report 2009 QuarterIV: 16). ${ }^{15}$ Bank loans are shifted toward policy-oriented sectors and regions, such as agriculture, small- and medium-sized enterprises, job creation, lessdeveloped western regions, etc. Such efforts are more obvious in recent years in an attempt to mitigate structural imbalances in China's economy - for example, unbalanced economic growth with the coexistence of overheating and under-developed sectors; the rising regional disparity, mainly between coastal and interior regions; the soaring income inequality, especially between rural and urban residents. Through credit policy tools, the PBC is actively engaged in directing bank lending and affecting the structure of bank loans. In general, these credit tools are more direct, yet administrative and discretionary. Most of central banks in advanced economies abolished them in the 1970 s and 1980 s.

Under the current operating procedure, both monetary policy tools and credit policy tools are informative about the stance of monetary policy. Thus, changes in the PBC's policy stance should be predicted through monitoring all policy tools (see also Chen, Chen, and Gerlach 2011; He and Pauwels 2008; Shu and Ng 2010; Xiong 2011). However, "explicit mention of all instrument variables is not in all circumstances the best possible description of monetary policy" (Kareken and Solow 1963: 76). Moreover, these policy instruments are so different in nature that it is impossible to summarize them into a single indicator.

Yet, if all the policy instruments move simultaneously in a comparable magnitude, it is nevertheless possible to use one instrument to represent the behavior of all others. Figure 1 shows the development of three selected policy instruments for the post-1998 period: the discount rate, the benchmark lending rate and the required reserve ratio. A close examination of these three instruments indicates that they did not always move together. Two interest rates initially showed a simultaneous movement, which however impaired after 2006. Changes in the required reserve ratio displayed divergences from the change pattern of interest rates: the correlation coefficient of the reserve ratio with the benchmark lending rate is 0.24 and that with the discount rate is even slightly negative, -0.03 . In particular, over the post-2006 period the PBC tended to use changes in reserve requirements more extensively, in terms of both the frequency and the magnitude. For example, in eighteen months throughout June 2008, the PBC almost doubled the required reserve ratio to 17.5

\footnotetext{
${ }^{15}$ According to Geiger (2006), window guidance has been effective in China given that the PBC can influence appointments of the senior personnel at commercial banks.
} 
percent in 16 steps while the benchmark lending rate was raised only modestly by 1.2 percentage points in 6 adjustments.

\section{Figure 1: Three selected monetary policy instruments in China: the required reserve ratio, the benchmark lending rate and the discount rate (in \%), 1998-2011 ${ }^{\mathrm{a}, \mathrm{b}}$}

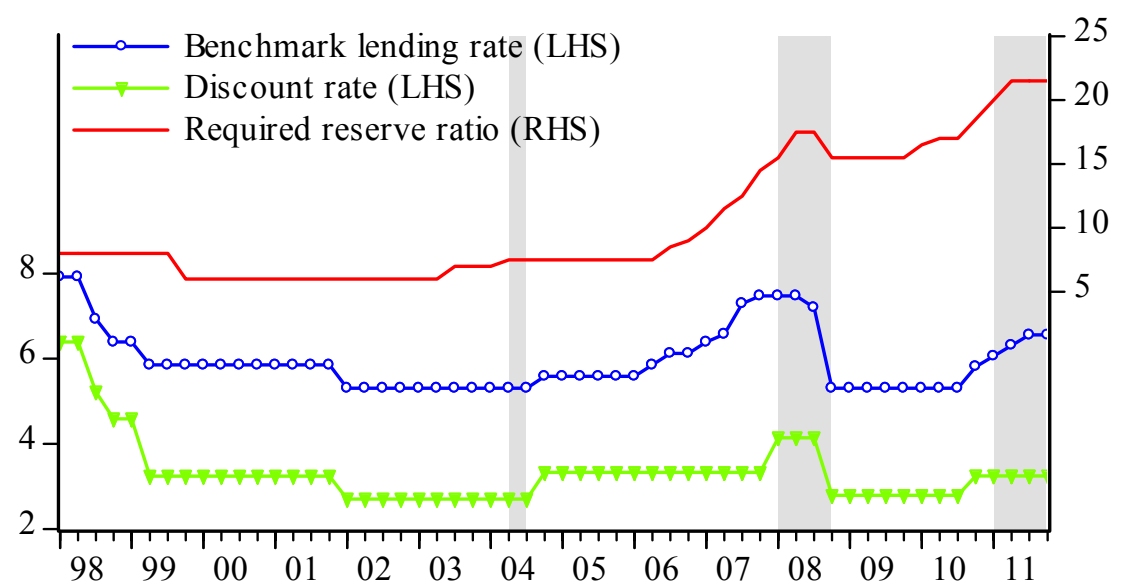

Notes: a. Starting from September 25, 2008, the reserve ratio for the small- and medium-sized financial institutions is set 1-2 percentage points lower than that for the big financial institutions. In the figure, the ratio for the big financial institutions is reported. b. The discount rate is an interest rate at which the PBC lends to commercial banks with a maturity of 20 days; the benchmark lending rate (with a maturity of 1 year) is an interest rates set by the $\mathrm{PBC}$ as a benchmark for banks to follow.

Grey shaded areas are marked as contractionary episodes, which will be elaborated in the following section.

Source: The minimum required reserve ratios are author's compilation based on the "Chronology" of various issues of the PBC's Annual Report. The interest rates are from IMF International Financial Statistics.

This shift is due to concerns that a rise in interest rates would be followed by capital inflows, which would elicit undesired increases in appreciation pressures on the RMB. Furthermore, keeping the domestic interest rate above the American one implies sterilization costs for the PBC. After foreign exchange purchases, the PBC used to take offsetting operations by issuing central bank bills to sterilize the monetary base. It buys foreign assets (mostly in the form of US government bonds) and sells central bank bills. The sterilization costs arise when the returns on US government bonds is smaller than the domestic interest rates on central bank bills. But sterilization could result in profits as long as the differential between two bond yields is positive. Indeed, there had been virtually no sterilization costs until October 2007 (see, e.g., Cappiello and Ferrucci 2008; Xie 2009). However, since November 2007 the domestic yields have exceeded the US bond yields ${ }^{16}$, sterilization has turned to be costly. These costs would be exacerbated if the appreciation of the RMB is taken into consideration. Eventually, the $\mathrm{PBC}$ has been more reluctant to use the interest rate tool.

\footnotetext{
${ }^{16}$ The Crisis has led to increasing demand for US government bonds (safe-haven effect) and a fall of their yields.
} 
On the other hand, the use of central bank bills for the sterilization purpose was "partly constrained by weaker purchasing willingness on the part of commercial banks" (China Monetary Policy Report 2006 Quarter II). In 2006, the PBC shifted to more extensive use of the required reserve ratio. It is direct and effective in influencing the money supply.

The current exchange rate regime predicates that as long as there are foreign exchange purchases, the PBC has to conduct large-scale open market operations, supplemented with raising reserve requirements, to sterilize the monetary base. The frequent changes in reserve requirements have drawn a lot of attention - they were publicly announced and newsworthy. Nevertheless, these changes are "not necessarily indicative of monetary easing or tightening, but are more related to the management of foreign exchange reserves", as the PBC's Governor, Zhou, Xiaochuan, pointed out (Caixin 2012). This suggests that a part of changes in policy instruments is systematic response of the PBC to the state of the economy. To isolate exogenous components of monetary policy changes from systematic policy responses requires more information on driving forces of policy movements.

\section{The Identification Problem}

The movements of the PBC's policy variables reflect more than policy changes. They incorporate large endogenous responses of monetary policy to current and expected economic developments. This section presents a simple framework to illustrate the identification problem inherent in the estimation of the effects of monetary policy. It further shows why estimates with conventional measures of monetary policy are likely to give rise to omitted-variable bias.

Suppose output is affected by the monetary policy variable $\Delta m$ (for example, conventional monetary policy measures such as a monetary aggregate, the money market rate, or other policy indicator) and some other factors:

$$
\Delta Y_{t}=\alpha_{0}+\alpha_{1} \Delta m_{t}+\alpha_{2} Z_{t}+\alpha_{3} E_{t}+\epsilon_{t},
$$

where $\Delta Y_{t}$ is the first difference of logarithm of real GDP. The vector, $Z$, summarizes many other factors that affect real growth, such as government spending, supply shocks and foreign demand shocks, while the vector, $E$, includes expectations about future developments. For simplicity, the lagged terms of variables are ignored. 
The PBC reacts to output and sets policy to achieve economic goals. When doing so, it watches a range of variables, including output growth and variables in the $Z$ and $E$ vector. Its policy reaction function can be written as:

$$
\Delta m_{t}=\beta_{0}+\beta_{1} \Delta Y_{t}+\beta_{2} Z_{t}+\beta_{3} E_{t}+\delta_{t}
$$

Rewriting Equation (2) yields:

$$
\Delta Y_{t}=\left(-\frac{\beta_{0}}{\beta_{1}}\right)+\frac{1}{\beta_{1}} \Delta m_{t}-\frac{\beta_{2}}{\beta_{1}} Z_{t}-\frac{\beta_{3}}{\beta_{1}} E_{t}-\frac{1}{\beta_{1}} \delta_{t},
$$

The rearranged policy reaction function, Equation (3), appears to have the same list of right-hand variables as Equation (1). We hence do not know what a simple regression of output on those variables tells us. Is it the effect of monetary policy on output, or the PBC's reaction function? Most likely, it is the mixture of these two. This is known as the identification problem. Only exogenous shocks to the monetary policy variable $-\delta_{t}$ in Equation (2), the monetary policy movements that are independent of output growth and other factors in the vector $Z$ and $E$ that affect output growth - can be used to identify the true effects of monetary policy on output.

However, even in the most sophisticated model, it is impossible to proxy for all information about future output movements that policymakers have had. Suppose that the true relationships between $\Delta Y$ and $\Delta m$ are represented in the system of Equation (1) and (2). Yet, the PBC's expectations about the future output movements are not observed. Thus, the vector $E$ is left out of the system:

$$
\begin{gathered}
\Delta Y_{t}=\gamma_{0}+\gamma_{1} \Delta m_{t}+\gamma_{2} Z_{t}+\vartheta_{t}, \\
\Delta m_{t}=\theta_{0}+\theta_{1} \Delta Y_{t}+\theta_{2} Z_{t}+\varphi_{t},
\end{gathered}
$$

The error terms in Equation (4) and (5) are $\vartheta_{t}=\alpha_{3} E_{t}+\epsilon_{t}$ and $\varphi_{t}=\beta_{3} E_{t}+\delta_{t}$, respectively. They are correlated. Clearly, the proxy for exogenous monetary policy shocks with the error term $\varphi_{t}$ will lead to biased estimates of monetary policy on output.

Obviously, this omitted-variable bias can be narrowed to some limit by including more control variables. However, the analysis of the PBC's operating procedure and history suggests that the PBC watches an enormous number of economic variables when setting policy. Many original macroeconomic data are not publicly available in China, neither are the PBC's numerical forecasts 
of future economic developments. Thus, left-out variables are a serious problem in the estimates of the PBC's monetary policy effects with simple regressions.

Another concern is that the PBC's operating procedures have experienced huge changes over time. Thus, its monetary policy reaction function cannot be well described with time-invariant Equation (2). Rather, the coefficients in its reaction function should vary from episode to episode. This suggests that a simple inclusion of more control variables into the system is unlikely to eliminate the bias.

Estimates of the effects of monetary policy with conventional measures rely crucially on the correct modeling of the interrelationship between economic variables and monetary policy measures. An alternative approach, the narrative approach, can be used to tackle both the indicator and identification problems. This approach "involves using the historical record, such as the descriptions of the process and reasoning that led to decisions by the monetary authority and accounts of the sources of monetary disturbances" (Romer and Romer 1989: 122). This information discloses the central bank's intentions for each policy movement. Some of these intentions are neither linked directly to output nor indirectly to those factors that are likely to affect output growth. In this way, I can single out those policy movements that are exogenous to the current and future economic developments in the real side.

Let the exogenous monetary policy movements be defined as $\Delta m_{t}^{u}$ such that:

$$
\Delta Y_{t}=\rho_{0}+\rho_{1} \Delta m_{t}^{u}+\omega_{t},
$$

where the error term, $\omega_{t}$, includes the impact of all other factors on output growth. This regression appears to be simple. But it should yield an unbiased estimate of the impact of monetary policy on output given that with the narrative approach, $\Delta m_{t}^{u \prime} s$ are identified as those monetary policy movements that are orthogonal to any other shocks in $\omega_{t}$ that might influence output growth. Hence, in the subsequent sections I will use this regression and some of its extension to estimate the effects of the PBC's monetary policy on output. On the other hand, unbiased estimates with a simple regression as Equation (6) relies crucially on the validity of its underlying identifying assumption that the identified shocks, $\Delta m_{t}^{u \prime} s$, are uncorrelated with other determinants of output growth. I thus complement my empirical analysis with various robustness tests in the last section to check this identifying assumption. 


\section{Narrative Identification of Monetary Shocks}

In this section, I apply the narrative approach to identify monetary policy shocks. An exogenous shock is precisely defined as a monetary movement driven by inflation, rather than by the state of the real economy. In this way, only those contractionary anti-inflationary policy movements are considered. The reason for using this narrow definition of monetary shock is that the concern about inflation appears to be the only driving force that fulfils the premise of being independent of the current and future developments of real output. First, inflation is mainly due to past shocks. And second, trend inflation by itself does not cause large short-run fluctuations in real output. On the contrary, monetary expansions are largely associated with real economic developments (for example, weak economic growth) and thus we can barely isolate exogenous policy changes from those endogenous policy responses to the state of the economy.

\subsection{Identification of Monetary Shocks}

I use two sources of documents from the PBC - "Press Release" on quarterly meetings of the Monetary Policy Committee (MPC) and China Monetary Policy Report. The MPC was established in July 1997. According to the PBC's Law, the Committee "shall play an important role in macroeconomic management and in the making and adjustment of monetary policy" (Article 12 of the PBC's Law). At the moment, it is composed of 15 members. ${ }^{17}$ Since 1999, it holds quarterly meetings to discuss current policy issues. After each meeting, the PBC discloses main contents of discussion by issuing a short press release. The press release covers the MPC's reviews of current economic developments and challenges ahead, its assessments of current monetary policy and in particular, its suggestion for the future monetary policy is clearly stated and explained. Based on this information, I single out those policy shifts when the MPC held the view that policy should shift to contraction to rein in inflation for the forthcoming quarter. These releases are made online on the PBC's homepage, though incomplete (only those from 2000 on are available).

As a cross check, I control my findings from "Press Release" with a comparison to China Monetary Policy Report, which is an executive summary of monetary policy and published each quarter by

\footnotetext{
${ }^{17}$ They include the PBC's Governor, two Deputy Governors; officials from government departments, such as the State Council, the State Development and Reform Commission, Finance Ministry; officials from banking, securities, and insurance regulatory authorities; and experts from the academia.
} 
the PBC since 2001. This Report covers analysis of the macroeconomic and financial situation and explains the monetary policy operations. One chapter addresses the PBC's policy intentions for the next period and policy changes are well explained. Throughout the overlapping sample period of 2001-2011, I did not find contradictory statements between two sources. Altogether, I identify three exogenous shocks when the PBC shifted to an anti-inflationary tightening. They are 2004 Q2; 2008 Q1-2008 Q3; and 2011 Q1-2011 Q4.

The end of contraction is defined when the PBC stopped showing concerns about inflation and announced a shift back to normal. ${ }^{18}$ In this way, the duration of each shock is specified, which is new compared to Romer and Romer (1989). One criticism on narrative-based monetary policy shocks is that these shocks contain no information about the magnitude of contraction and they are treated homogenously. Certainly, identifying the duration of each shock weakens this critique as the length of the episode sheds light on the degree of contraction. The longer the episode, the more severe the contraction is. Thus, contractions can be evaluated on a heterogeneous basis.

2004 Q2. The steadily rapid growth of money stock and bank lending in 2002 and 2003 made inflation a real risk in 2004. Inflation in the first quarter of 2004 grew at a rate of 3 percent, after being negative for years. At its meeting in March 2004, the MPC held the view that it was time to take actions to prevent inflation. "Money and credit growth should be properly controlled.... No negligence should be tolerated in preventing inflation and financial risks" ("Press Release" on the First Quarter 2004 MPC Meeting). For the next period, monetary policy should be "appropriately tight" and the PBC "will closely monitor the price changes" (China Monetary Policy Report 2004 Quarter I).

The contractionary episode lasted only one quarter as at the end of the second quarter, "the strong growth momentum of money supply and loans had been reined in, and the macro financial control measures had produced expected result" ("Press Release" on the Second Quarter 2004 MPC Meeting). The MPC agreed that the prudent monetary policy should be adopted in the coming period.

\footnotetext{
${ }^{18}$ Quite often, the PBC describes its normal policy as "the prudent monetary policy" (it was originally translated as "sound monetary policy", yet starting from 2009 the PBC translated it as "prudent monetary policy"). The "prudent" monetary policy is an activist policy with the PBC maintaining an appropriate money growth rate so as to support the sustainable, steady and healthy growth of GDP (China Monetary Policy Report, Quarter 4 2010).
} 
2008 Q1-2008 Q3. Starting from 2007, the PBC got concerned about the build-up of inflationary pressure on the grounds of the more-than-expected growth of money and bank lending. In the second half of 2007, prices grew at a rate of 6 - 8 percent, mainly due to rapid rises in food and oil prices. At two MPC meetings in the fourth quarter of 2007 and the first quarter of 2008, the Committee repeatedly emphasized that "efforts should be made to ... prevent shifts ... from structural price rise to full-scale inflation." For the coming periods, "the Committee held the view that a tight monetary policy should be implemented" ("Press Release" on the Fourth Quarter 2007 and on the First Quarter 2008 MPC Meeting). By June 2008, the PBC still held the view that "the inflationary pressure was noticeable"; "curbing excessive price increase" and "containing inflation" should be taken as top priorities ("Press Release" on the Second Quarter 2008 MPC Meeting).

From July 2008, inflation showed a decelerating trend: from 7 percent in June to 4.6 percent in September. In September 2008, Lehman Brothers went bankruptcy and the US subprime mortgage crisis spilled over to the real economy. At its September's meeting, the MPC agreed to end the tightening.

2011 Q1-2011 Q4. In 2010, inflation crept up from 1.5 percent to 5.1 percent. At its December 2010 meeting, the MPC held the view that the PBC was facing tough tasks in controlling money, credit and liquidity growth. The MPC agreed that for the next year, monetary policy should "give more priority to stabilizing the general price level" and "efforts should be made to control liquidity and bring the monetary and credit conditions back to a normal state" ("Press Release" on the Fourth Quarter 2010 MPC Meeting). Inflation continued in 2011 and reached 6.5 percent in July. At its first three meetings in 2011, the MPC reemphasized that monetary policy should attach top priority to inflation control and various measures should be taken to effectively manage the liquidity and keep credit and money aggregates at reasonable levels.

Inflation started to slow down in August 2011 and reached 4.1 percent in December. At its December 2011 meeting, the MPC agreed that the Chinese economy faced complex domestic and external situation due to the European debt crisis and for the coming period, a prudent monetary policy should be taken. 


\subsection{Were Shocks Predictable?}

Figure 2 plots the dynamic of inflation from 2000 to 2011, together with three identified episodes, which are marked in grey shaded areas. In each case, inflation went up gradually. All these contractionary shifts always happened around the local peaks of inflation. Yet, the PBC's response to inflation does not appear to be deterministic. The "unacceptable" inflation rates varied largely across three identified episodes: they were 3 percent, 6.5 percent and 4.6 percent, respectively, at the PBC's decision for 2004 QII, 2008 QI and 2011 QI contraction.

Figure 2: The inflation rate (in \%, annualized), 2000-2011

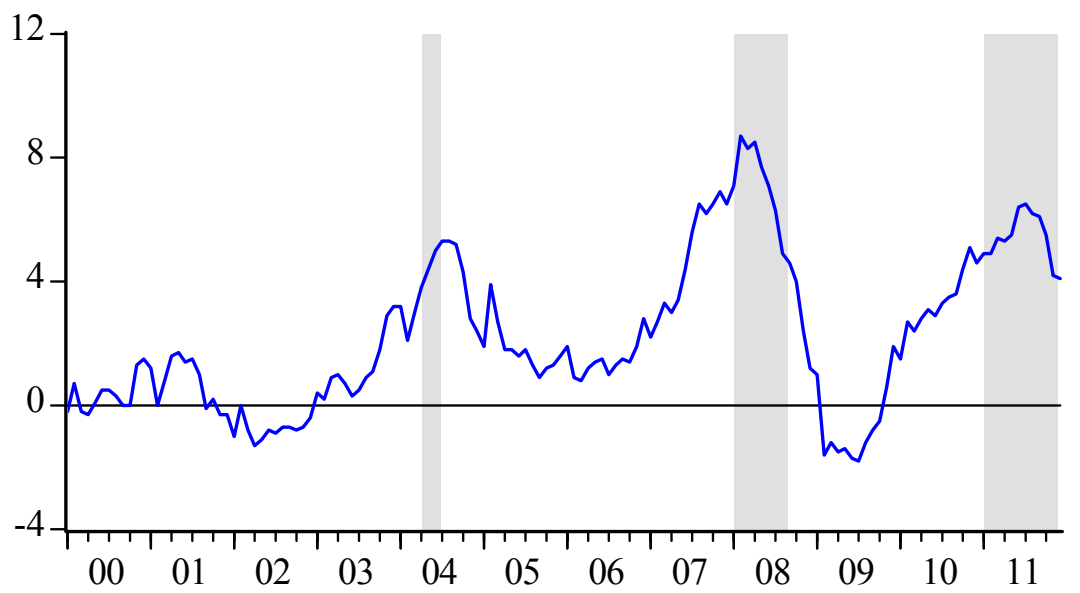

Notes: The inflation rate is calculated as a percentage change of the consumer price index (CPI). Grey shaded areas are marked as identified contractionary episodes.

Source: Monthly data from Datastream.

The exogeneity of policy shocks suggests that shocks are not predictable. Yet, Leeper (1997) found that in a logit model, the Romer and Romer (1989)'s dates were highly predicted by lagged economic variables. ${ }^{19}$ He concluded that these shocks were not exogenous. However, this finding should be interpreted with caution because the predictability was largely due to overfitting of the model, as pointed out by Romer and Romer (1997). ${ }^{20}$ Nevertheless, it sheds the light on the importance to examine the predictability of the narrative monetary policy shocks.

\footnotetext{
${ }^{19}$ Shapiro (1994) made another test, finding that future inflation and unemployment did not highly predict the Romer and Romer dates.

${ }^{20}$ Overfitting arose as the Leeper's logistic model was too complex with too many parameters (37 parameters altogether) relative to the limited variation in the dataset (a time series of the Romer and Romer dummy with only 7 observations equal to one).
} 
I test the Leeper critique with my identified policy shocks in a logistic model, which is parallel to the Leeper's specification, but more parsimonious. This logit model says that when the PBC's tolerance of inflation exceeded a certain threshold, it stopped accommodative policy and shifted to monetary tightening. It is given as follows:

$$
E\left(D_{t}^{S} \mid \Omega_{t}\right)=F(\alpha, \bar{X})
$$

where $E\left(^{\cdot}\right)$ is a expectation term; $D_{t}^{S}$ is a policy shift dummy variable, which takes value of 1 in the month, when the PBC decided to shift policy to anti-inflationary; and 0 otherwise ${ }^{21} \Omega_{t}$ stands for the PBC's information set, which includes the most recent developments of two macroeconomic variables, output and inflation. These two variables reflect costs and benefits that the PBC considers in determining whether to move to anti-inflationary policy. On the right-hand side of the equation, $F\left({ }^{\prime}\right)$ is a logistic function and $\alpha$ is a constant term; $\bar{X}=\left(\bar{g}_{I P}, \bar{\pi}\right)^{\prime}$ is the list of macroeconomic variables in the information set, with $\bar{g}_{I P}=\frac{\sum_{i=1}^{3} g_{I P, t-i}}{3}$ standing for the average growth rate of industrial production for the previous three months and $\bar{\pi}=\frac{\sum_{i=1}^{3} \pi_{t-i}}{3}$ for that average inflation rate. In so doing, I try to avoid overfitting by limiting the number of coefficients that need to be estimated. ${ }^{22}$ On the other hand, I use the average values of the past three months to proxy for a possibly large information set of the PBC.

The time series data of industrial production growth are available on a monthly basis, but discontinuous, with January data since 2005 missing. The reason for that is the unconventional method that the Chinese National Bureau of Statistics uses in solving the seasonality problem inherent in time series. The growth rate of industrial production is calculated by comparing industrial production over the same period last year. ${ }^{23}$ For example, the growth rate for $2011 \mathrm{M}_{\mathrm{j}}$ is calculated as $g_{I P, 2011 M_{j}}=\left(\frac{I P_{2011 M_{j}}}{I P_{2010 M_{j}}}-1\right) * 100$, with $j=1,2, \ldots, 12$, giving a percentage change of industrial production in month $\mathrm{M}_{\mathrm{j}}$ over year. In so doing, the time series of industrial production

\footnotetext{
${ }^{21}$ That is, $D_{t}^{S}=1$, when $t=$ April 2004, February 2008 and February 2011. Note that the 2008 and 2011 contractionary shifts are defined in February because the January observations on industrial production growth are not available.

${ }^{22}$ Rather than averages of three lags of industrial production growth and inflation, I examine two variants of Equation (7) by defining the PBC's information set to either only one lag or three lags of IP growth and inflation, and obtain quite similar results.

${ }^{23}$ The original data are not publicly available.
} 
growth should not contain any seasonal variations. ${ }^{24}$ However, there are still abnormal fluctuations in the beginning of some years due to Chinese New Year effects.

The Chinese New Year, the most important family festival in China, based on the Chinese lunar calendar, takes place either at the end of January or in February. Officially, it is a three-day public holiday. Yet, many migrant workers from the rural area quit shortly before the Chinese New Year to travel home, or take a weeks-long holiday. Therefore, the holiday effects on the output level in the corresponding month could be even larger. This leads to large fluctuations in industrial production growth for the years that are adjacent, but have the Holiday in different months. ${ }^{25}$ In 2005, the Chinese authorities stopped publishing industrial production growth for January. Instead, industrial production in January and February was added up and the growth rate for such an aggregate was calculated. I correct the data before 2005 in the same way to keep it consistent and eliminate Holiday effects. In this way, the time series of industrial production growth has only 11 observations for each year.

The data used in this paper are mainly from Datastream, except those specifically indicated. The sample period hereafter is from January 2000 to December 2011. Yet, when industrial production is included in the estimates, I adjust other time series by dropping out January observations to accommodate the industrial production data. In those cases, the sample period starts with February 2000.

Table 3 presents the estimation results of three variants of Equation (7), which differ in the regressands included. ${ }^{26}$ In all three specifications, the coefficients before the lagged inflation and the lagged industrial production growth both have the right sign as the theory predicts: higher inflation and higher output growth raise the probability of a policy shift to contraction. Yet, none of them is statistically significant. In the most general specification, 3.c, the joint null hypothesis that coefficients before both explanatory variables are zero cannot be rejected at the high significance level (19 percent). All three regressions have a low $R^{2}$, indicating poor fit of the prediction equation.

\footnotetext{
${ }^{24}$ That is, March of this year, for example, typically has the same number of working days, weather, and other variables that might affect output as March of last year.

${ }^{25}$ For example, the industrial production growth rate was 2.3 percent in January and 19 percent in February 2001, respectively, as the Chinese New Year fell in January for the year 2001 but in February for the year 2000.

${ }^{26}$ Given the limited variation of the data, this logistic model is still on the borderline of overfitting despite all my efforts to model in a parsimonious way. In fact, using it to test the predictability of policy shifts tends to overstate the degree of endogeneity of policy movements.
} 
Table 3: Decision to shift to contraction: logistic estimates ${ }^{a}$

\begin{tabular}{lccc}
\hline & $3 . \mathrm{a}$ & $3 . \mathrm{b}$ & $3 . \mathrm{c}$ \\
\hline Constant & $-5.01^{* *}$ & -8.09 & -8.35 \\
& $(1.23)$ & $(4.44)$ & $(5.05)$ \\
Inflation $(\bar{\pi})$ & 0.37 & & 0.33 \\
& $(0.23)$ & & $(0.24)$ \\
Output Growth $\left(\bar{g}_{I P}\right)$ & & 0.28 & 0.22 \\
& & $(0.27)$ & $(0.31)$ \\
Summary statistic & & & \\
McFadden (Pseudo) R-squared & 0.09 & 0.05 & 0.12 \\
Probability(LR statistic) & 0.10 & 0.23 & 0.19 \\
\hline
\end{tabular}

\footnotetext{
Notes: a. The logistic estimates are based on Equation (7). For more details, see the text. b. Probability (LR test) is the p-value of the LR test statistic, which tests the joint null hypothesis that all slope coefficients except the constant are zero.

Monthly data are used. Standard errors are in parentheses. ** indicates that a null hypothesis of zero is rejected at the 1 percent level.

Source: Author's estimations.
}

The probability of an anti-inflationary policy shift implied by these logistic estimates is presented in Figure 3. Vertical green dotted lines mark the dates of the actual policy shift. A comparison of Panel A and Panel B suggests that inflation plays more important role in predicting a policy shift, though the fitted probability of the 2004 April contraction is mainly associated with the output variable. Throughout all three specifications, the predictability is low. For example, according to the most-generally-specified model, as shown in Panel C, the predicted probability of three contractions is $0.03,0.09$ and 0.02 , respectively. Evidently, the PBC's shift to contraction is not predictable.

I extend this predictability test further by considering an alternative specification. Given that the exchange rate stability is one of the PBC's policy objectives, I include the trade balance, which is likely to influence the exchange rate, into the logistic model (the graph will not be reported due to the space constraint). Accounting for the trade balance (as a ratio of GDP) does not change the results. The $R^{2}$ is 0.19 , slightly higher. The coefficient before the lagged trade balance is negative, as expected, but not statistically significant (neither are the other two coefficients). The predicted probability is eventually the same for the 2008 and 2011 contractions as that in Panel C of Figure 3. Yet, the predicted probability for 2004 contraction is increased to 0.16 . It suggests that the trade balance plays some limited role in predicting 2004 contraction only. 
Figure 3: Implied probability of an anti-inflationary policy shift

Panel A: Estimates with the lagged inflation only

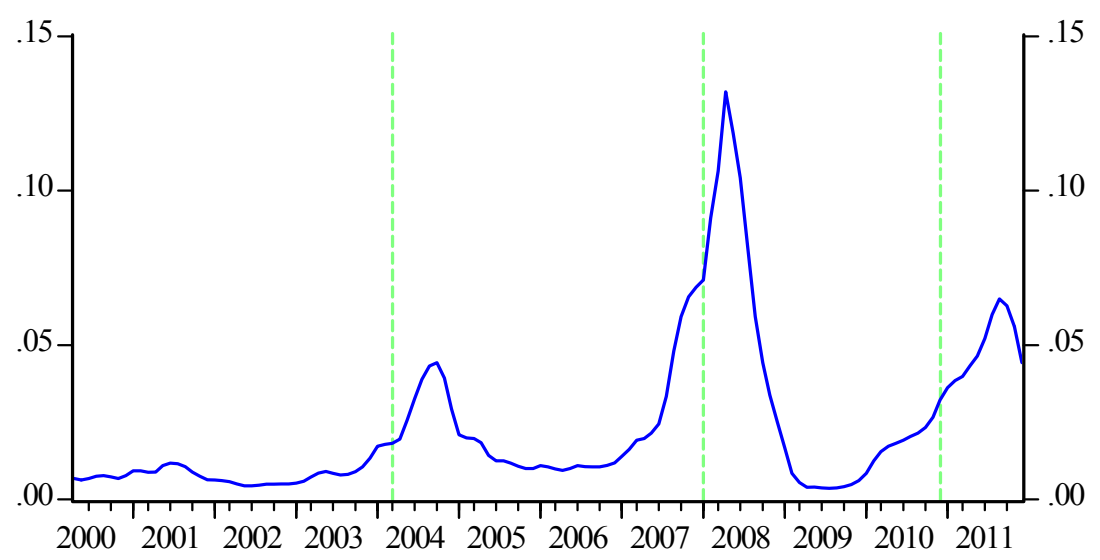

Panel B: Estimates with the lagged industrial production growth rate only

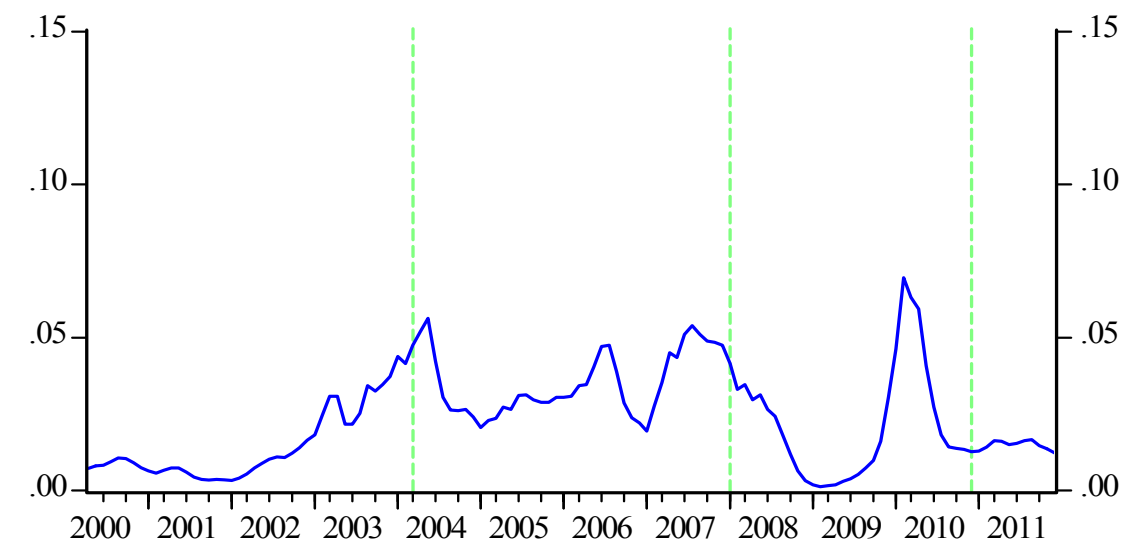

Panel C: Estimates with both the lagged inflation and the industrial production growth rate

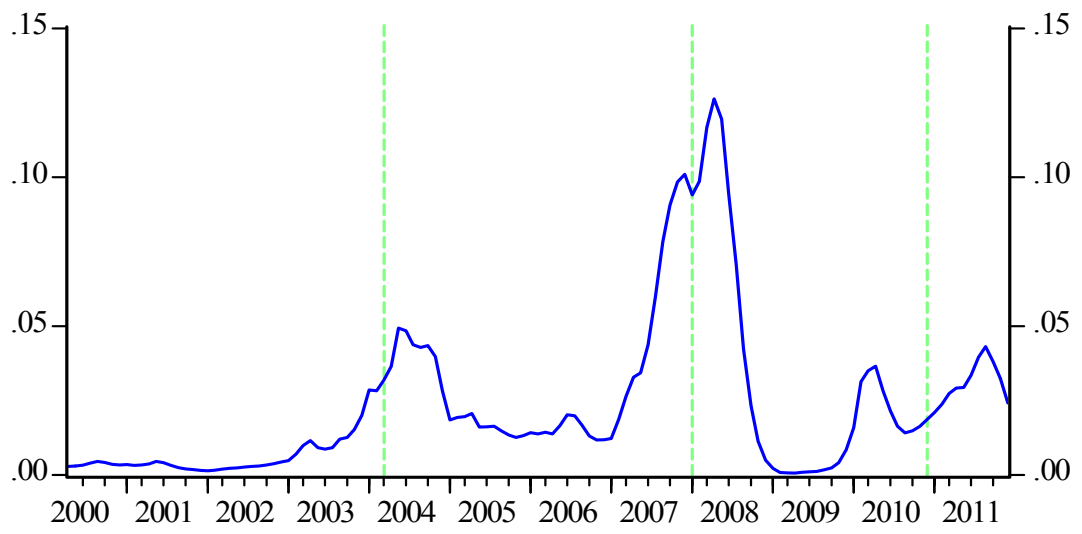

Notes: See notes of Table 3. Vertical green dotted lines mark identified actual policy shift dates. Source: Author's estimations. 


\subsection{Intensions versus Actions}

Three policy shock episodes are identified when the PBC made a clear statement that monetary policy should shift to contraction to rein in inflation. However, one can argue that intensions are not necessarily followed by actions. A quick check of the PBC's policy actions indicates that after each anti-inflationary decision, the PBC indeed took various tightening measures in those episodes. Figure 1, presented in the previous section, shows the evolution of three selected policy tools, the required reserve ratio and two interest rates, together with the identified episodes, marked in grey shaded areas. In each episode, the PBC used all these three tools to lower inflation. In April 2004, the $\mathrm{PBC}$ raised both the interest rates and the required reserve ratio; in the first half of 2008, the PBC raised the required reserve ratio to 17.5 percent in seven continuous adjustments, together with increases in the interest rates; again in 2011, the reserve ratio was hiked to 21.5 percent, a recordhigh level, and interest rates were increased as well.

\section{How Do Monetary Shocks Affect the Economy?}

To quantitatively estimate effects of monetary policy on the economy, I introduce a monetary contraction dummy variable that equals 1 in the episodes when monetary policy is identified to be contractionary, and 0 otherwise. This time series for the monetary contraction dummy thus has $D_{t}=$ 1 if $t=2004: 4-2004: 6,2008: 1-2008: 9$ and 2011:1-2011:12, and $D_{t}=0$ otherwise.

\subsection{The Baseline Results}

The impact on output. The contraction dummy series reflects changes in monetary policy exogenous to the real economic developments. With these exogenous shocks, I thus can use the simple specification for the baseline estimation, similar to Equation (6) in Section 3, but including the lagged terms, which considers dynamics of output growth and at the same time allows monetary policy to affect output beyond the current period:

$$
g_{I P, t}=a_{0}+\sum_{j=1}^{11} b_{j} g_{I P, t-j}+\sum_{k=0}^{11} c_{k} D_{t-k}+e_{t},
$$

where $g_{I P}$ is growth of industrial production and $D$ is the monetary contraction dummy. I include 11 lags of industrial production growth. ${ }^{27}$ This autoregression part accounts for some inherent

\footnotetext{
${ }^{27}$ This is because the monthly data of industrial production growth contain only 11 observations.
} 
boom-and-bust cyclical movements of output. The current and 11 lags of monetary policy measure are included, ${ }^{28}$ which captures the impact of monetary policy on output.

With the regression results of Equation (8) (see Table B.1 in the appendix), the implied impact of exogenous monetary restrictions on output is computed. For example, following a one-unit rise in $D$, the estimated response of industrial production growth in the contemporaneous month is simply the coefficient on the contemporary term of $D, c_{0}$; the estimated response after one month is $c_{0}+\left(c_{1}+\right.$ $b_{1} c_{0}$ ); and so on so forth (see Romer and Romer 2004). This response combines the direct effect of a monetary contraction on output and the feedback effect through lagged output.

Figure 4 presents implied impact of a shift to a monetary contraction on industrial production growth, together with one-standard-error bands. ${ }^{29}$ This hump-shaped pattern of the impact is very similar to those estimates obtained in the literature for other countries (see, e.g., Christiano, Eichenbaum, and Evans 1999; Romer and Romer 2004; Sims 1992). After the PBC shifts to contraction, industrial production starts to fall with a two-month delay. Then it declines quickly after 6 months. The maximum impact is found after 15 months: the anti-inflationary shift reduces industrial production by about 5.9 percent, compared to what it would otherwise be. After hitting the trough, industrial production rebounds slightly, but remains at a substantially negative level: about -4.8 percent after three years, ${ }^{30}$ although the precision of the estimation deteriorates with a rising horizon. Monetary policy has strong and persistent effects on output.

\footnotetext{
${ }^{28}$ With an inclusion of the current term of the monetary contraction dummy, monetary disturbances are allowed to have contemporaneous effects on real output.

${ }^{29}$ The asymptotic standard errors of the impulse response function are computed according to the formula specified by Poterba, Rotemberg and Summers (1986: 668).

${ }^{30}$ It remains at this level even after five years.
} 
Figure 4: Estimated impact of monetary tightening on industrial production (baseline simple regression)

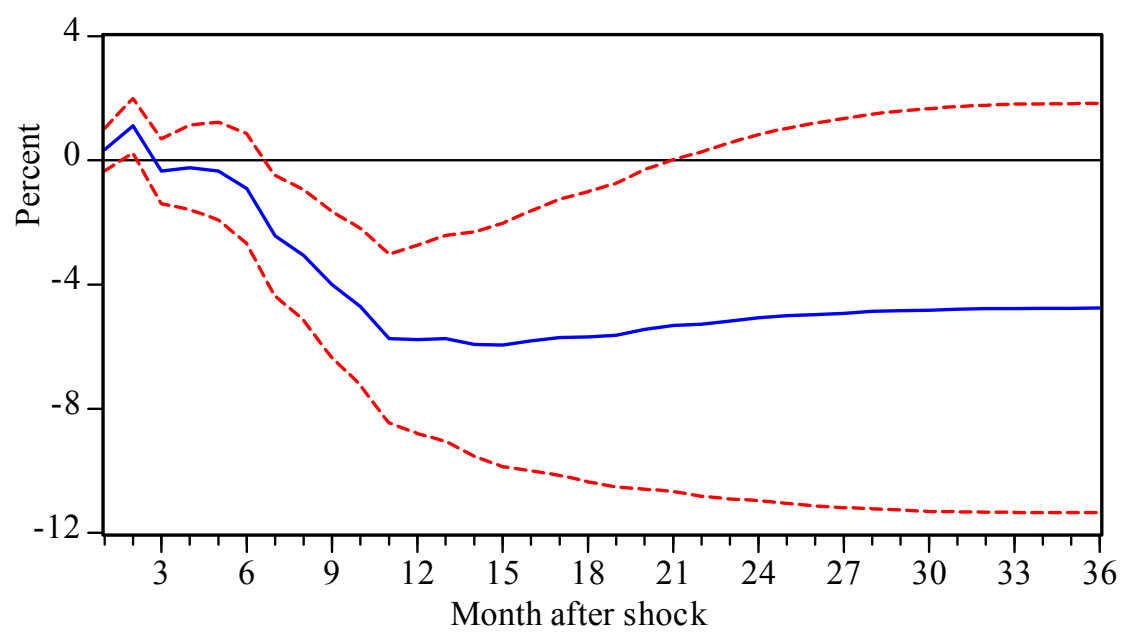

Notes: The implied effects are computed cumulative responses of industrial production growth to a one-unit rise of the contraction dummy, based on the estimation of Equation (8) (see Table B.1 in the appendix). The dotted lines are one-standard-error bands.

Source: Author's estimation.

The impact on inflation. The PBC shifted to contraction with the intention to control inflation. The natural question is thus whether this tightening has effects on the price level. The baseline regression is as follows:

$$
\pi_{t}=a_{0}+\sum_{j=1}^{24} b_{j} \pi_{t-j}+\sum_{k=0}^{24} c_{k} D_{t-k}+e_{t}
$$

where $\pi$ is inflation rate, calculated as a percentage change of the consumer price index over years, similar to the method used in computing industrial production growth. Given that monetary policy is likely to affect rigid prices with larger delay, I include more lags, altogether 24.

Table B.2 in the appendix summarizes the regression results of Equation (9). Its implied impact of a monetary contraction on inflation is reported in Figure 5, together with one-standard-error bands. The point estimates suggest that following a tightening, prices do fall, though with a substantial delay. Prices first rise, small and insignificantly. Starting from the eighth month, they drop steadily. After one and a half year, the price level is about 5.9 percent lower than what it would otherwise have been. ${ }^{31}$ Afterwards, prices start to rise and the impact remains negative ( -2.6 percent) after 36 months. Yet, statistical uncertainty about this result is large.

\footnotetext{
${ }^{31}$ The implied sacrifice ratio (the ratio of the total industrial production loss to the change in inflation) of the PBC's disinflation policy is about 5.9 percent $/ 5.9$ percent $=1$ after one year and a half.
} 


\section{Figure 5: Estimated impact of monetary tightening on the price level} (baseline simple regression)

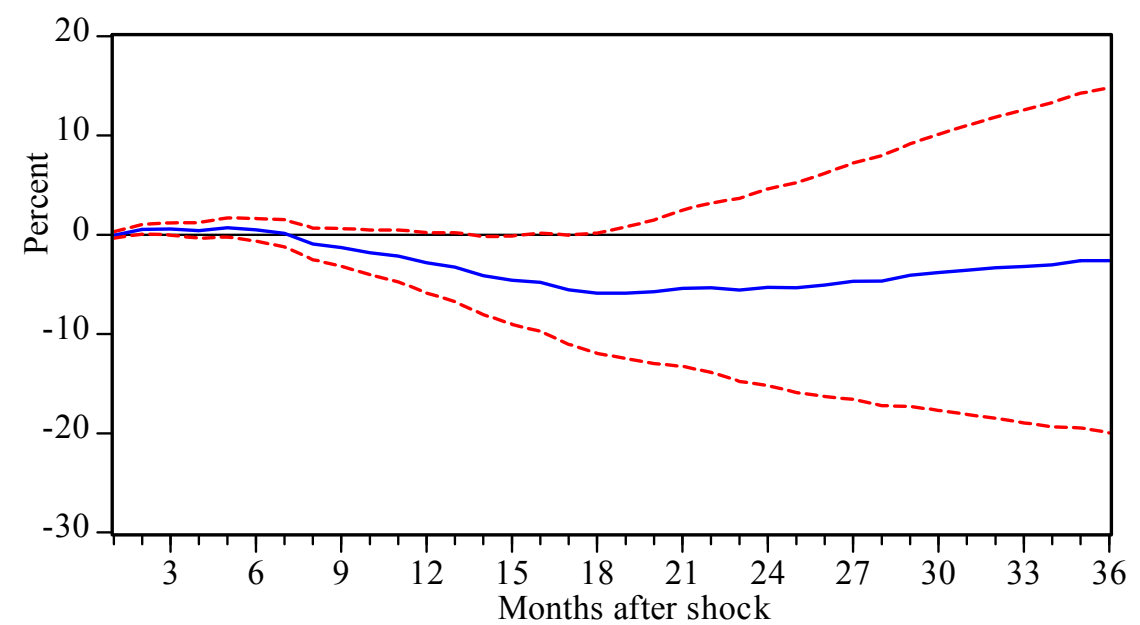

Notes: The impulse response is computed based on the estimation of Equation (9) (see Table B.2 in the appendix). For more explanations, see notes of Figure 4.

Source: Author's estimation.

\subsection{The VAR Results}

I consider another specification by extending the baseline regressions to a bivariate vector autoregression (VAR) which allows for effects of both lagged output (inflation) and past policy changes on the monetary contraction dummy. This extension can be viewed as a robustness check. ${ }^{32}$ My test of the exogeneity of identified policy shifts in Section 4.2 indicated that the past developments of output and inflation do not have any significant effects on the policy shifts. Hence, we expect to get similar results from the VAR approach.

To be consistent with the baseline regression, I allow monetary policy to affect the economy contemporaneously in the VAR. Thus, the equation for the monetary contraction dummy is ordered first and industrial production growth (inflation) second in the VAR system.

I run two bivariate VARs. Figure 6 shows the results. Panel A presents the responses of industrial production growth to a contractionary monetary shift, together with one-standard-error bands. Panel $\mathrm{B}$ shows the impact on inflation. The VAR results are compared with the implied impacts of monetary policy estimated from the baseline single-equation regression, which are repeated in both

\footnotetext{
${ }^{32}$ Leeper (1997) provides such a robustness test for the Romer and Romer (1989)'s results by contrasting the VAR results with the ones that the Romers obtained.
} 
panels. The VAR estimation, allowing for the endogeneity of the monetary contraction dummy, does not change the main results.

\section{Figure 6: Estimated impact of monetary tightening (bivariate VAR)}

Panel A. Impact on industrial production

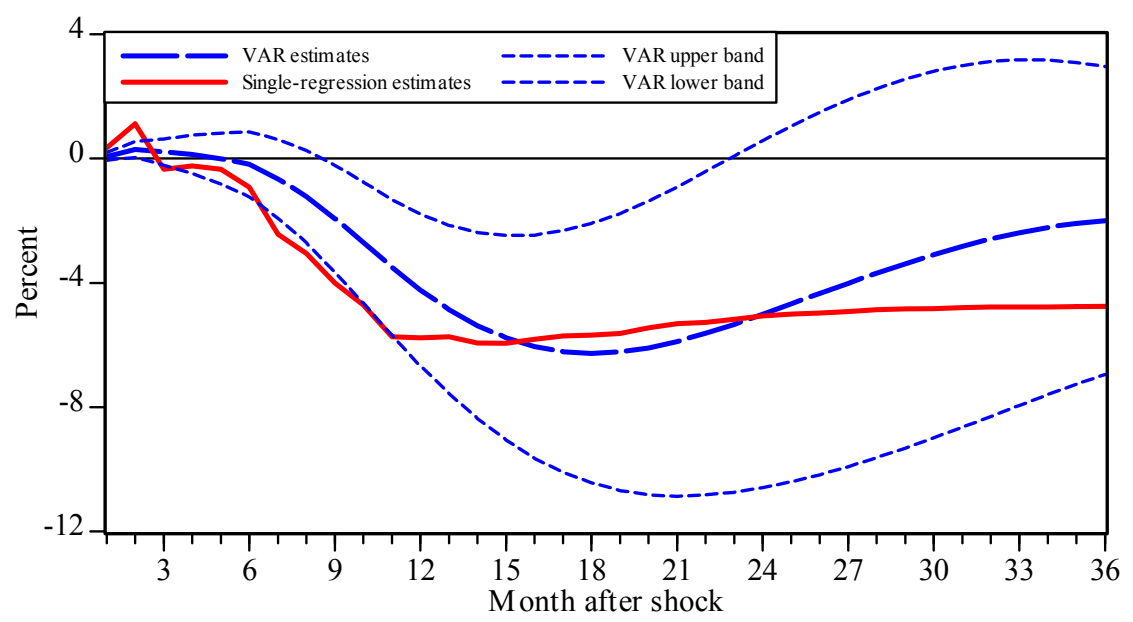

Panel B. Impact on the price level

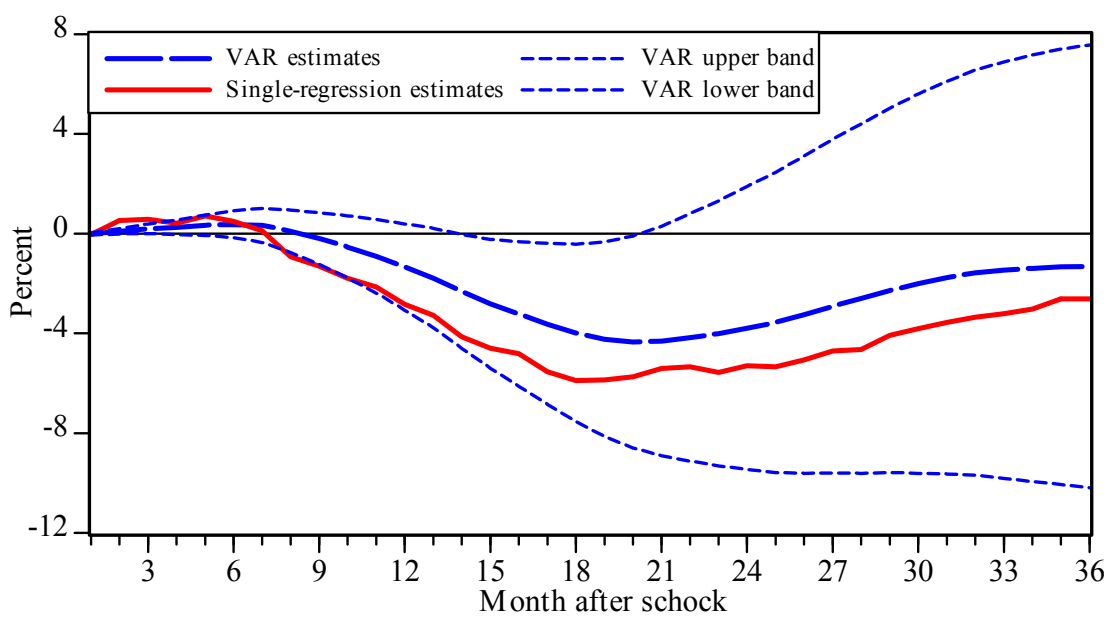

Notes: The cumulated impulse responses of industrial growth (Panel A) and prices (Panel B) are estimated separately in two bivariate VARs with the monetary contraction dummy and industrial production growth (or inflation).

Source: Author's estimation.

Again in the VAR estimates, the responses of industrial production to monetary tightening follow the hump-shaped pattern, with a slightly larger delay. The estimated maximum decline of industrial production occurs at the end of 18 months and is actually slightly larger (-6.3 percent compared to 5.9 percent). Yet, the VAR suggests that this decline is less severe with output rebounding more quickly. The negative impact falls to about -2 percent after 3 years. 
The VAR estimation for prices yields the same sluggish response pattern of prices to monetary tightening. Prices are first sticky and start to decline after the eighth month. Then, the two sets of estimates show a parallel co-movement at all horizons. Yet, the effects estimated in the VAR framework are in general 1.5 percent smaller than those from the simple regression. The VAR estimated maximum effect is a decline of prices of 4.4 percent. Overall, the confidence interval is substantial. The VAR estimates appear to be less precise.

\subsection{Comparison with Other Measures}

The motivation for this paper to use the narrative approach is due to two concerns about how to measure Chinese monetary policy. First, the conventional measures that are widely used to measure monetary policy of other central banks may not be able to sufficiently reflect the PBC's policy changes given that the PBC applies a wide range of policy instruments and does not necessarily change all of them simultaneously. The second one is that the conventional measures contain reaction components of the central banks to the current and expected economic developments. As shown in Section 3, using these endogenous conventional measures to estimate the real effect of monetary policy may lead to an omitted-variable bias. It is therefore useful to compare my results based on the narrative exogenous measure with those using the conventional measures to see if this bias indeed exists.

In this section, we consider four other measures. The first one is the Shu-Ng narrative index. As mentioned in the introduction, Shu and $\mathrm{Ng}$ (2010) read the PBC's documents and build an index time series to indicate the stance of the PBC's monetary policy. I consider their five-value index, ranging from -2 (very easy) to 2 (very tight), available over the sample period from January 2001 to June 2009. Another two measures are the growth rate of the broad money stock (the year-over-year growth rate of M2) and the interest rate (I consider the prime lending rate with the maturity of one year or less), both of which are widely used to measure monetary policy of other central banks. The fourth measure that I consider is the required reserve ratio given the fact that the PBC has been extensively using this policy tool.

Panel A of Figure 7 shows the implied impact of monetary tightening on industrial production estimated with the regressions (parallel to Equation 8) using these four measures as the policy indicator each in turn. Panel B shows the impact on the price level based on the regressions (parallel 
to Equation 9). For comparison, the results using my narrative exogenous policy measure are repeated in both panels. ${ }^{33}$ The comparison focuses mainly on the response patterns given that the impulses based on different measures are not comparable. Overall, the results suggest that the estimates based on other measures are either puzzling or biased with slow and transient responses.

\section{Figure 7: Estimated impact of monetary tightening using other measures}

Panel A. Impact on industrial production

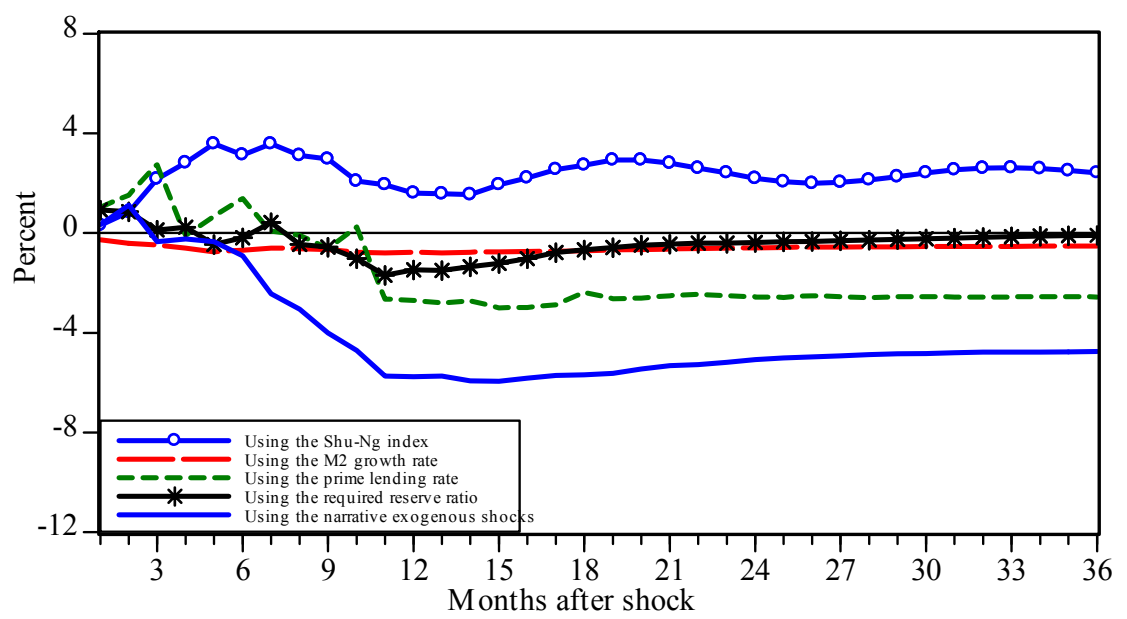

Panel B. Impact on the price level

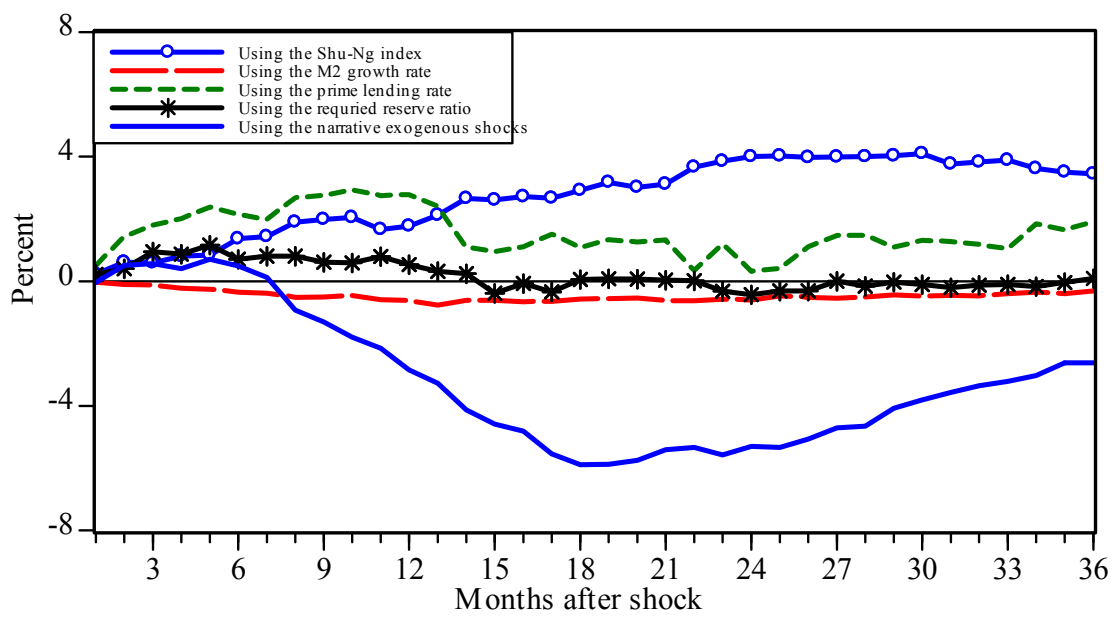

Notes: The figures present the implied impact of monetary tightening on industrial production (Panel A) and the price level (Panel B), based on the regression specification similar to Equation (8) and (9), respectively, but using different monetary policy measures each time.

Source: Author's estimation.

\footnotetext{
${ }^{33}$ The confidence intervals of all the estimates are not reported to keep the figures readable.
} 
Surprisingly, the Shu-Ng index performs the worst. The results by using this index show that monetary tightening induces a rise in both output and the price level, which is inconsistent with what the theory predicts. It implies that although the Shu-Ng index precisely measures the policy stance of the PBC by summarizing all records information, it still contains many policy response components. Special efforts are required to search for a right model to disentangle those endogenous components if one attempts to use it in estimating the impact of monetary policy.

The estimates by using the interest rate show that after a rise in the interest rate, output falls, but after eight months. This output response is slower compared to the results using my narrative exogenous shocks. The maximum impact of a one-percentage-point rise in the interest rate on output is around -3 percent after about one and half years. However, the estimates predict that after a rise in the interest rate, prices increase. This result is puzzling (known as the price puzzle in the literature) as the theory suggests the opposite.

The results based on the required reserve ratio suggest that output starts to decline with a larger delay. Then, this effect dies out quickly after about one and half years. Correspondingly, a rise in the reserve ratio has virtually null impact on inflation. Prices first rise moderately and fall to slightly negative after fifteen months. Thereafter, prices fluctuate around the zero line.

The estimates by using the M2 growth rate show that following a monetary contraction with a onepercentage-point reduction of the money supply, both output and the price level fall immediately and remain moderately negative at all horizons.

The results by using these four measures indicate that the endogeneity of these measures is a severe problem and using them is very likely to lead to puzzling or biased estimates of the policy impact. The puzzle and bias are not easily dealt with. My attempt to control for the endogeneity of these policy measures in a bivariate (VAR) with output (or inflation) and the policy measure ends in vein (due to the space constraint, the results are not reported here). The price puzzle still exists in the estimates based on the Shu-Ng index, the interest rate and the required reserve ratio. Neither is the prediction based on the Shu-Ng index for output corrected: industrial production increases following monetary tightening. Obviously, a simple VAR model cannot sufficiently disentangle exogenous policy changes from endogenous response components. This is a particular challenge for the study of China's monetary policy as the PBC's reaction cannot be simply described with a time- 
invariant response function over the period when the PBC's operation procedures experienced large evolutionary changes.

\subsection{Robustness}

So far, monetary policy appears to have strong and persistent impact on real output in China. In this section, I clarify several concerns about the robustness of these results.

Was inflation different across episodes? Inflation was the main factor that explained the PBC's contractionary policy shift. The first concern is hence whether the inflation that I identified was driven by some common factors. If it is the case, then these factors could account for fluctuations in real output that I found. Yet, my reading of the PBC's analysis about inflation did not suggest that there was such a common driving force. Rather, inflation was different across episodes. In $2003 / 2004$, it was the build-up of liquidity in the banking system that drove up prices. In 2007/2008, high inflation was triggered by rapid rises in food prices, including cereal, pork and poultry, and oil prices. In 2010/2011, several factors led to rises in prices: first, expansionary monetary policy in major industrialized countries has caused capital inflows into emerging markets, driving up asset prices there; second, the depreciation of the reference currency (the US dollar) contributed to rises in commodity prices; third, domestically, the unit production cost stepped up as a result of rising labor costs (see China Monetary Policy Report 2010 Quarter IV). In sum, inflation in three identified episodes was largely caused by past shocks, with the specific driving forces varying across episodes.

Is a slowdown due to inflation? Given that inflation is clearly visible during all shock episodes, the concern arises whether the identified economic slowdown was due to inflation. In fact, there is neither theory nor evidence showing that inflation by itself (independent of supply shocks) has direct impact on real output. Nonetheless, I test whether controlling for inflation will change the results by including the current and 11 lags of inflation (based on the producer price index) into Equation (8). ${ }^{34}$ The regression results suggest that accounting for a direct effect of inflation on output has little impact on the timing and the persistence of the response of industrial production to a monetary shock. The maximum impact is found at the end of the first year, but somehow smaller

\footnotetext{
${ }^{34}$ The data are adjusted with the January observations omitted.
} 
(about -4 percent). This negative impact of monetary contraction on output is persistent and remains at the substantial level (around -3.7 percent even after five years).

Is a slowdown due to adverse supply shocks? I extend the robustness test further and ask whether adverse supply shocks around the times of the policy shifts were the true driving force of the economic slowdown. ${ }^{35}$ Energy price changes based on the purchasing price index for fuel and power, published by National Bureau of Statistics of China, ${ }^{36}$ are used as a proxy to measure adverse supply shocks. I include the current and 11 lags of energy price changes into Equation (8). Controlling for energy price shocks does not change the implied impact of monetary tightening on output. Industrial production declines with a small delay and after about one year, it is about 6 percent lower than what it would otherwise have been. Again, this substantial negative impact is perennial.

Controlling for fiscal policy. Another concern is that the identified effects on output may not purely stem from anti-inflationary monetary policy. For example, the central government of China might implement all kinds of policies to fight inflation. I test this argument by controlling for fiscal policy in my simple regression. I extend Equation (8) by including the current and 11 lags of the ratio of budget surplus/deficit to nominal GDP. ${ }^{37}$ Accounting for fiscal policy does not mitigate the estimated effects of monetary policy on output. Industrial production falls quickly after a fourmonth delay. After about one year, the negative impact of monetary tightening on output is about -6 percent. Similar to my results using my narrative exogenous measure, this impact remains substantial and persistent.

\section{Conclusion}

As a fast growing emerging economy, China has attracted the world's attention. Yet, its institutions and functioning framework remain different from those in advanced economies. This paper enriches

\footnotetext{
${ }^{35}$ Indeed, Hoover and Perez (1994) and Romer and Romer (1994) argue on whether the estimated monetary policy impact on the output, found by Romer and Romer (1989), is due to oil shocks.

${ }^{36}$ The data are available only since January 2003.

${ }^{37}$ Alternatively, one can use government spending to measure fiscal policy, which is not possible given that the monthly data on Chinese government expenditures are available only over a shorter sample period (since June 2007). Nonetheless, the high correlation between budget surplus/deficit and government spending over this sample period (-0.9) suggests that budget surplus/deficit can well proxy for fiscal policy.
} 
the literature by looking into the institutional details of the PBC, focuses on how and with what effects monetary policy is implemented in China.

At the moment, the PBC uses many policy instruments and none of them can be described as its principal tool. Its operational procedures still vary over time. Its reaction function can hardly be described with a time-invariant equation. All the PBC's institutional specifics suggest that the conventional monetary policy measures can neither sufficiently reflect its policy changes nor can estimates using those conventional measures be free of bias. To overcome these measurement challenges, I use the narrative approach in this paper to disentangle the PBC's exogenous policy changes from its endogenous components. For the period of 2000-2011, I identify three exogenous policy changes as those driven by inflationary pressure. These exogenous policy shocks are uncorrelated with developments on the real side of economy. Their impact on the economy gives an unbiased estimate of the effects of monetary policy.

Estimates using the shocks that I have identified indicate that monetary policy in China has strong effects on output. My baseline regression suggests that a shift to fight inflation lowers industrial production by almost 6 percent. This is further confirmed by most of my robustness tests. Another important finding is that this suppression appears to be perennial with the negative impact remaining at a substantial level even after five years, though the estimates are becoming less precise with an increase in the time horizon. 


\section{Appendix A: Data Appendix}

\section{A.1: Institutional background of the PBC from 1998 to 2011}

Targeted money growth rates for M1 and M2: Targets announced by the PBC on the annual basis, partly adopted from Geiger (2006) and partly the author's compilation;

Actual growth rates of $M 1$ and M2: Annual growth rates calculated as yearly percentage changes of M1 and M2, Datastream;

Minimum required reserve ratio: On the quarterly basis, the author's compilation based on the "Chronology" of various issues of the PBC's Annual Report;

Discount rate: The interest rate at which the PBC lends to commercial banks with a maturity of 20 days, on the quarterly basis, IMF International Financial Statistics;

Benchmark lending rate: The interest rate (with a maturity of one year or less) set by the PBC as a benchmark for commercial banks to follow, on the quarterly basis, IMF International Financial Statistics.

\section{A.2: Macroeconomic data}

All data series are monthly from January 2000 to December 2011 (except those specifically mentioned).

$D$ : The exogenous monetary contraction dummy, identified by the author through reading the PBC's documents;

$g_{I P}$ : The annualized growth rate of industrial production, Datastream;

$\pi$ : The annualized inflation rate based on the consumer price index, Datastream;

Trade balance: Its ratio to nominal GDP is used, Datastream;

Shu-Ng narrative index: The index to indicate the policy stance of the PBC, Shu and $\mathrm{Ng}(2010)$;

$g_{M 2}$ : The annualized growth rate of M2 on the monthly basis, Datastream;

Prime lending rate: The benchmark lending rate set by the $\mathrm{PBC}$ with the maturity of one year or less, Datastream;

Energy price shocks: The changes in the purchasing price index for fuel and power, available only from January 2003 on, National Bureau of Statistics of China;

Ratio of budget surplus/deficit to nominal GDP: Datastream. 


\section{Appendix B: Baseline Regression Results}

Table B.1: Baseline regression results for industrial production

\begin{tabular}{ccccccc}
\hline & \multicolumn{2}{c}{ Montary policy shock } & & \multicolumn{3}{c}{ Change in industrial production } \\
\cline { 1 - 3 } \cline { 5 - 6 } Lag & Coefficient & Standard error & & Lag & Coefficient & Standard error \\
\hline 0 & 0.35 & 0.68 & & 1 & $0.77^{* *}$ & 0.10 \\
1 & 0.49 & 0.93 & & 2 & 0.18 & 0.13 \\
2 & $-2.12^{*}$ & 0.91 & & 3 & 0.12 & 0.13 \\
3 & 1.06 & 0.94 & & 4 & -0.14 & 0.13 \\
4 & 0.02 & 0.93 & & 5 & -0.05 & 0.13 \\
5 & -0.20 & 0.92 & & 6 & -0.10 & 0.13 \\
6 & -1.21 & 0.92 & & 7 & 0.12 & 0.13 \\
7 & 0.65 & 0.93 & & 8 & 0.11 & 0.13 \\
8 & -0.42 & 0.94 & & 9 & -0.13 & 0.13 \\
9 & 0.39 & 0.94 & & 10 & -0.04 & 0.13 \\
10 & -0.23 & 0.94 & & 11 & 0.04 & 0.10 \\
11 & 0.61 & 0.75 & & & &
\end{tabular}

Summary statistic

Number of observations

121 after adjustement

Adj. R-squared

0.84

Standard error of regression

1.35

DW statistic

2.03

Notes: The regression is based on the estimation of Equation (8). The estimates of the constant term are not reported. * and $* *$ indicate that a null hypothesis of zero is rejected at the 5 percent and 1 percent level, respectively.

Source: Author's estimation. 
Table B.2: Baseline regression results for inflation

\begin{tabular}{|c|c|c|c|c|c|}
\hline \multicolumn{3}{|c|}{ Montary policy shock } & \multicolumn{3}{|c|}{ Change in CPI } \\
\hline Lag & Coefficient & Standard error & Lag & Coefficient & Standard error \\
\hline 0 & -0.03 & 0.32 & 1 & $0.99 * *$ & 0.12 \\
\hline 1 & 0.59 & 0.44 & 2 & 0.04 & 0.17 \\
\hline 2 & -0.50 & 0.43 & 3 & -0.05 & 0.17 \\
\hline 3 & -0.24 & 0.45 & 4 & 0.00 & 0.17 \\
\hline 4 & 0.49 & 0.45 & 5 & 0.07 & 0.18 \\
\hline 5 & -0.51 & 0.45 & 6 & -0.06 & 0.19 \\
\hline 6 & -0.21 & 0.46 & 7 & 0.13 & 0.19 \\
\hline 7 & -0.62 & 0.45 & 8 & 0.16 & 0.19 \\
\hline 8 & 0.61 & 0.45 & 9 & -0.27 & 0.19 \\
\hline 9 & -0.22 & 0.46 & 10 & -0.06 & 0.19 \\
\hline 10 & 0.29 & 0.48 & 11 & 0.16 & 0.19 \\
\hline 11 & -0.28 & 0.48 & 12 & -0.57 & 0.17 \\
\hline 12 & 0.13 & 0.53 & 13 & $0.39 *$ & 0.17 \\
\hline 13 & 0.04 & 0.55 & 14 & 0.08 & 0.18 \\
\hline 14 & 0.40 & 0.55 & 15 & -0.16 & 0.18 \\
\hline 15 & 0.14 & 0.54 & 16 & -0.06 & 0.18 \\
\hline 16 & -0.33 & 0.52 & 17 & 0.04 & 0.18 \\
\hline 17 & 0.20 & 0.52 & 18 & 0.09 & 0.18 \\
\hline 18 & 0.39 & 0.51 & 19 & 0.04 & 0.18 \\
\hline 19 & -0.28 & 0.50 & 20 & 0.10 & 0.18 \\
\hline 20 & 0.44 & 0.51 & 21 & -0.12 & 0.17 \\
\hline 21 & -0.33 & 0.51 & 22 & 0.12 & 0.17 \\
\hline 22 & -0.49 & 0.50 & 23 & -0.23 & 0.18 \\
\hline 23 & 0.15 & 0.50 & 24 & 0.08 & 0.11 \\
\hline 24 & 0.01 & 0.42 & & & \\
\hline \multicolumn{6}{|c|}{$\underline{\text { Summary statistic }}$} \\
\hline \multicolumn{2}{|c|}{ Number of observations } & \multicolumn{2}{|c|}{120 after adjustement } & & \\
\hline \multicolumn{2}{|c|}{ Adj. R-squared } & \multicolumn{2}{|l|}{0.96} & & \\
\hline \multicolumn{2}{|c|}{ Standard error of regression } & 0.51 & & & \\
\hline \multicolumn{2}{|c|}{ DW statistic } & 2.08 & & & \\
\hline
\end{tabular}

Notes: The regression is based on the estimation of Equation (9). The estimates of the constant term are not reported. * and $* *$ indicate that a null hypothesis of zero is rejected at the 5 percent and 1 percent level, respectively.

Source: Author's estimation. 


\section{$\underline{\text { References }}$}

Alesina, Alberto, Carlo Favero, and Francesco Giavazzi. 2012. The Output Effect of Fiscal Consolidations. NBER Working Paper Series No. 18336.

Bernanke, Ben S., and Alan Blinder. 1992. The Federal Funds Rate and the Channels of Monetary Transmission. American Economic Review 82(4) (Sep.):901-921.

Bernanke, Ben S., and Mark Gertler. 1995. Inside the Black Box: The Credit Channel of Monetary Policy Transmission. The Journal of Economic Perspectives:27-48.

Bernanke, Ben S., and Ilian Mihov. 1998. Measuring Monetary Policy. Quarterly Journal of Economics 113 (3):869-902.

Blanchard, Olivier J. 1990. Why Does Money Affect Output? A Survey. In Handbook of Monetary Economics, edited by B. M. Friedman and F. H. Hahn: Elsevier.

Caixin. 2012. Central Banker Says Monetary Policy Rests on Forex Flows. http://english.caixin.com/201203-12/100367241.html, on March 12, 2012.

Cao, Tinggui. 2001. The People's Bank of China and its Monetary Policy. Business Institute Berlin at the Fachhochschule für Wirtschaft Berlin, Working Paper No. 14, 2001.

Cappiello, Lorenzo, and Gianluigi Ferrucci. 2008. The Sustainability of China's Exchange Rate Policy and Capital Account Liberalisation. ECB Occasional Paper Series No. 82.

Chen, Hongyi, Qianying Chen, and Stefan Gerlach. 2011. The Implementation of Monetary Policy in China: The Interbank Market and Bank Lending. HKIMR (Hong Kong Institute of Monetary Research) Working Papers No. 26/2011.

Christiano, Lawrence J. , Martin Eichenbaum, and Charles L. Evans. 1999. Monetary Policy Shocks: What Have We Learned and to What End? In Handbook of Macroeconomics, edited by J. B. Taylor and M. Woodford: Elsevier.

Dickinson, David, and Jia Liu. 2007. The Real Effects of Monetary Policy in China: An Empirical Analysis. China Economic Review 18 (1):87-111.

Friedman, Benjamin M. 1995. Does Monetary Policy Affect Real Economic Activity?: Why Do We Still Ask This Question? In NBER Working Paper No. 5212.

Friedman, Benjamin M., and Kenneth N. Kuttner. 1992. Money, Income, Prices, and Interest Rates. The American Economic Review: 472-492.

1996. A Price Target for US Monetary Policy? Lessons from the Experience with Money Growth Targets. Brookings Papers on Economic Activity:77-146.

Friedman, Milton, and Anna J. Schwartz. 1963. A Monetary History of the United States 1867-1960. Princeton: Princeton University Press.

Geiger, Michael. 2006. Monetary Policy in China (1994-2004): Targets, Instruments and Their Effectiveness Wuerzburg Economic Working Paper No. 68.

Goldfeld, Stephen M., and Daniel E. Sichel. 1990. The Demand for Money. Handbook of Monetary Economics 1:299-356.

He, Dong, and Laurent L. Pauwels. 2008. What Prompts the People's Bank of China to Change Its Monetary Policy Stance? Evidence from a Discrete Choice Model. China \& World Economy 16 (6):1-21.

Hoover, Kevin D., and Stephen J. Perez. 1994. Post Hoc Ergo Propter Once More: An Evaluation of 'Does Monetary Policy Matter?' in the Spirit of James Tobin. Journal of Monetary Economics 34 (1):47-74.

Kareken, John, and Robert M. Solow. 1963. Lags in Monetary Policy. In Stabilization Policies. Englewood Cliffs, N.J.: Prentice-Hall.

Leeper, Eric M. 1997. Narrative and VAR Approaches to Monetary Policy: Common Identification Problems. Journal of Monetary Economics 40 (3):641-657.

Montes-Negret, Fernando. 1995. China's Credit Plan: An Overview. Oxford Review of Economic Policy 11 (4):25-42.

OECD. 2010. OECD Economic Surveys: China 2010 Paris: OECD Publishing.

People's Bank of China. Annual Reports, various issues.

People's Bank of China. China Monetary Policy Report, various issues.

People's Bank of China. Press Release (on Quarterly Meetings of Monetary Policy Committee), various issues.

People's Bank of China. 2012. 
http://www.pbc.gov.cn/publish/jinrongshichangsi/1023/2010/20100915164335804922955/20100915 164335804922955_html.

Poterba, James M., Julio J. Rotemberg, and Lawrence H. Summers. 1986. A Tax-Based Test for Nominal Rigidities. The American Economic Review: 659-675.

Ramey, Valerie A. 2011. Identifying Government Spending Shocks: It's all in the Timing. The Quarterly Journal of Economics 126 (1):1-50.

Ramey, Valerie A., and Matthew D. Shapiro. 1998. Costly Capital Reallocation and the Effects of Government Spending. Carnegie-Rochester Conference Series on Public Policy 48:145-194.

Romer, Christina D., and David H. Romer. 1989. Does Monetary Policy Matter? A New Test in the Spirit of Friedman and Schwartz. NBER Macroeconomics Annual:121-170. 1994. Monetary Policy Matters. Journal of Monetary Economics 34 (1):75-88.

1997. Identification and the Narrative Approach: A Reply to Leeper. Journal of Monetary Economics 40 (3):659-665.

2004. A New Measure of Monetary Shocks: Derivation and Implications. The American Economic Review 94 (4):1055-1084.

2010. The Macroeconomic Effects of Tax Changes: Estimates Based on a New Measure of Fiscal Shocks. The American Economic Review 100 (3):763-801.

Shapiro, Matthew D. 1994. Federal Reserve Policy: Cause and Effect. In Monetary Policy, edited by N. G. Mankiw. Chicago and London: University Of Chicago Press.

Shu, Chang, and Brian Ng. 2010. Monetary Stance and Policy Objectives in China: A Narrative Approach. Hong Kong Monetary Authority China Economic Issues 1/10.

Sims, Christopher A. 1992. Interpreting the Macroeconomic Time Series Facts: the Effects of Monetary Policy. European Economic Review 36(5) (Jun.):975-1000.

Sun, Lixin, Jim L. Ford, and David G. Dickinson. 2010. Bank Loans and the Effects of Monetary Policy in China: VAR/VECM Approach. China Economic Review 21 (1):65-97.

Xie, Hailin. 2009. A Study on the Sterilization Costs of the PBC's Central Bank Bills: A Study Based on the Monthly Data for the Period from March 2006 to December 2008 (in Chinese). Development Study (005):35-38.

Xie, Ping. 2004. The Analysis of China's Monetary Policy in 1998-2002. Journal of Finance 2004-08.

Xiong, Weibo. 2011. Measuring the Monetary Policy Stance of the People's Bank of China: An Ordered Probit Analysis. China Economic Review. 